\title{
smat
}

http://journal.binadarma.ac.id/index.php/olympia

\section{Pengaruh Permainan Sepakbola Terhadap Peningkatan Kebugaran Jasmani}

\section{Endie Riyoko ${ }^{1}$}

Universitas PGRI Palembang, Indonesia ${ }^{1}$

\begin{tabular}{l} 
Info Artikel \\
\hline Sejarah Artikel: \\
Diterima Januari 2019 \\
Disetujui Februari 2019 \\
Dipublikasikan Maret \\
2019
\end{tabular}

Keywords: football games, physical fitness

\begin{abstract}
Abstrak
Masalah dalam penelitian ini adalah $95 \%$ tingkat kebugaran jasmani siswa putra di SMA Srijaya Negara Palembang yang dijadikan sampel masih sangat rendah sehingga apabila siswa sudah melakukan pembelajaran penjasorkes, siswa merasa lelah setelah melakukan aktivitas olahraga. Tujuan dari penelitian ini adalah untuk mengetahui adakah pengaruh permainan sepak bola terhadap peningkatan kebugaran jasmani di SMA Srijaya Negara Palembang. Sampel dalam penelitian ini diambil 25 siswa dari populasi siswa putra yang berjumlah 69. Berdasarkan hasil penelitian dan analisis data disimpulkan bahwa nilai rata-rata siswa putra setelah diterapkan latihan berupa permainan sepak bola adalah 11,36 jika dibandingkan sebelumnya dengan nilai rata-rata 10,08. Hal tersebut menunjukkan bahwa nilai posttest lebih besar dari pada pretest $(11,36>10,08)$.
\end{abstract}

\begin{abstract}
The problem in this research is the $95 \%$ level of physical fitness student Srijaya Negara high school son of Palembang, which provided the sample is still very low so that when students are already doing physical education learning, students feel tired after doing sports activities. The purpose of this research is to know is there any influence of football games against the increase of physical fitness in high school Srijaya Negara. The sample in this research taken 25 students from the student population of son amounted to 69. Based on the results of research and data analysis, it was concluded that the average value of the student's son after applied exercises in the form of football games is 11.36 if compared with the average value of 10.08. It indicates that the value is larger than the posttest on pretest $(11.36>10,08)$.
\end{abstract}

Alamat korespondensi: Jl. Jend Ahmad Yani, Lr. Gotong Royong, 9/10 Ulu, Seberang Ulu I, Kota Palembang, Sumatera Selatan 30116

E-mail: endieriyoko@ rocketmail.com 


\section{PENDAHULUAN}

Pada dasarnya manusia akan selalu berkeinginan untuk memiliki kesehatan dan kesegaran jasmani karena manusia merupakan makhluk individu yang tidak terlepas dari jasmani dan rohani. Sama halnya dengan kata olahraga, merupakan kata Indonesia asli, yang memiliki arti olah yaitu mengolah sedangkan raga adalah jasmani, menjadi satu kesatuan yang tak terpisahkan. Untuk mewujudkan kesegaran atau kebugaran jasmani seseorang dapat melakukan dengan berbagai cara, tetapi yang paling efektif adalah dengan melakukan olahraga secara teratur dan berkesinambungan dan disesuaikan dengan jenis kelamin dan usia. Untuk mempertahankan kesegaran pada usia di atas 40 tahun bisa melakukan olahraga 4 kali dalam satu minggu dengan porsi yang telah ditentukan misalnya jalan sejauh 3 sampai dengan $6 \mathrm{~km}$, atau dengan melakukan kegiatan olahraga selama 45 menit hingga satu jam (Sukirno, 2011:269).

Secara khusus pentingnya pembinaan olahraga disekolah karena kegiatan olahraga dapat mengembangkan dan membangun kepribadian, watak, budi perkerti luhur dan moral tinggi serta inisiatif. Karena pnyelenggaraan pembinaan olahraga bagi individu dan masyarakat ini, mengandung pendidikan yang positif, selain itu olahraga dapat menghilangkan rasa kedaerahan dan kesukuan serta mempertebal rasa persatuan dan kesatuan Nasional. Hal ini dapat terlihat pada pertandingan-pertandingan atau kejuaraan-kejuaraan olahraga seperti Pekan
Olahraga Nasional (PON) yang mempertandingkan berbagai macam olahraga dan salah satunya adalah sepak bola (Ajick, 2009).

Pertandingan sepak bola dimainkan oleh dua tim yang masing-masing beranggotakan 11 orang. Masing-masing tim mempertahankan gawang dan mencoba menjebolkan gawang lawan, kiper diperbolehkan untuk mengontrol bola dengan tangannya di dalam daerah pinalti yaitu daerah yang berukuran lebar 44 yard dan 18 yard pada garis akhir. Pemain lainnya tidak diperbolehkan menggunakan tangan atau lengan mereka untuk mengontrol bola, tapi mereka dapat menggunakan kaki, tungkai, atau kepala. Gol diciptakan dengan menendang atau menanduk bola ke dalam gawang lawan, setiap gol dihitung dengan skor satu, dan tim yang paling banyak menciptakan gol pemenangnya (Luxbacher, 2011:2). Pemain sepak bola harus memiliki teknik dasar yang mempuni, seperti mengumpan (passing), menghentikan atau mengontrol (stoping), menggiring (dribbling), dan menembak (shooting) (Purnama, 2014).

Menurut Nurhasan (2001:130) siswa yang memiliki derajat kebugaran jasmani yang tinggi, akan menopang terhadap aktivitas kegiatan belajarnya dan meningkatkan kinerja serta mampu untuk melakukan aktivitas fisik lainnya. Menurut Nurhasan (2001:133) adapun dalam kebugaran jasmani terdapat komponen-komponen kebugaran jasmani antara lain: 
1. Kebugaran jasmani yang berpengaruh dengan kesehatan meliputi : Daya tahan jantung paru, Kekuatan otot, Daya tahan otot, Kelenturan, Komposisi tubuh

2. Kebugaran jasmani yang berpengaruh dengan keterampilan meliputi : Kecepatan, Kekuatan, Keseimbangan, Kelincahan, Koordinasi, Waktu reaksi.

Kualitas latihan merupakan suatu hal yang penting dalam usaha meningkatkan mutu dan prestasi seorang atlet. Latihan-latihan yang bermanfaat serta mempunyai arah dan tujuan yang jelas. Suatu latihan yang intensif belum dapat dikatakan sudah cukup bilamana latihan tersebut tidak disertai bobot, mutu, dan kualitas dari latihan itu sendiri. Dalam latihan juga perlu diperhatikan variasi latihan karena dengan adanya variasi-variasi dalam menghindarkan dari rasa bosan dan jenuh. Banyak pelatih yang menggunakan pada lamanya latihan daripada pembebanan latihan. Waktu latihan sebaiknya pendek tapi berisi dan padat dengan kegiatan yang bermanfaat, suatu keuntungan bila suatu latihan dalam waktu pendek adalah setelah mengikuti latihan atlet masih berpikiran tentang hal-hal yang berhubungan dengan latihan tersebut. Tetapi latihan dilakukan dengan jangka waktu yang panjang dan melelahkan maka bahayanya bahwa latihan tersebut merupakan suatu siksaan bagi atlet. Dalam latihan juga perlu relaksasi, relaksasi merupakan salah satu faktor yang penting dalam olahraga. Pengertian relaksasi adalah hilang atau berkurangnya ketegangan-tegangan baik bersifat fisik ataupun mental pada diri seseorang. (Priatama, 2014: 18).

\section{METODOLOGI PENELITIAN}

Metodologi Penelitian ini mengunakan metode eksperimen (Quasi - experimental design) dikarenakan pada kenyataannya sulit mendapatkan kelompok kontrol yang digunakan untuk penelitian. Menurut Sugiyono (2014:107) dalam penelitian eksperimen ada perlakuan (treatment), sedangkan dalam penelitian naturalistik tidak ada perlakuan. Dengan demikian metode penelitian eksperimen dapat diartikan sebagai metode penelitian yang digunakan untuk mencari pengaruh perlakuan tertentu terhadap yang lain dalam kondisi yang terkendalikan.

\section{Rancangan Penelitian}

Rancangan penelitian ini menggunakan rancangan One-Group Pretest-Posttest Design dengan demikian hasil perlakuan dapat diketahui lebih akurat, karena dapat membandingkan dengan keadaan sebelum diberi perlakuan. Berikut ini adalah rancangan dari penelitian tersebut :

\section{$\mathrm{O}_{1} \times \mathrm{O}_{2}$}

(Sumber: Sugiyono, 2014:111)

\section{Populasi dan Sampel Penelitian \\ Populasi Penelitian}

Populasi adalah merupakan wilayah generalisasi yang terdiri dari obyek/subyek yang memiliki kuantitas dan karakteristik tertentu yang ditetapkan oleh peneliti untuk 
dipelajari dan kemudian ditarik ditetapkan untuk diteliti. Instrument yang kesimpulannya. Itulah definisi populasi dalam penelitian (Sora N, 2015). Berdasarkan masalah dan tujuan penelitian maka yang menjadi populasi dalam penelitian ini adalah siswa putra SMA Srijaya Negara Palembang. Adapun rincian populasi dalam penelitian ini dapat dilihat pada tabel berikut ini:

Tabel 2. Populasi Penelitian

\begin{tabular}{|c|c|c|}
\hline No & Kelas & Jumlah \\
& & Laki-laki \\
\hline 1 & X & 25 \\
\hline 2 & XI & 23 \\
\hline 3 & XII & 21 \\
\hline \multicolumn{2}{|c|}{ Jumlah } & 69 \\
\hline
\end{tabular}

(Sumber : TU SMA Srijaya Negara 2018 )

\section{Sampel Penelitian}

Selanjutnya penentuan jumlah sampel dalam penelitian ini diambil menggunakan tekhnik Sampling Purposive dikarenakan penentuan sampel dengan pertimbangan penelitian menggunakan tingkatan umur dari 15-17 tahun sehingga menggunakan kelas atas, diambil 25 siswa saja dari populasi siswa putra yang berjumlah 69 , untuk lebih jelasnya dapat dilihat pada tabel 2 berikut ini.

Tabel 3 Sampel Penelitian

\begin{tabular}{|c|c|c|}
\hline No. & Kelas & Laki-laki \\
\hline 1 & $\mathrm{X}$ & 25 \\
\hline \multicolumn{2}{|c|}{ Jumlah } & 25 \\
\hline
\end{tabular}

Sumber : Peneliti 2018

\section{Teknik Pengumpulan Data}

\section{Instrumen Penelitian}

Jumlah instrumen penelitian tergantung pada jumlah variabel penelitian yang telah

digunakan untuk mendapatkan data hasil penelitian melalui tes kebugaran jasmani menurut Nurhasan (2001 :148) bahwa tes kebugaran jasmani untuk usia siswa SMA putra umur 15-17 tahun terdiri dari :
a. Lari 40 meter
b. Gantung siku tekuk
c. Baring duduk, 30 detik
d. Loncat tegak
e. Lari 600 meter

\section{Teknik Analisa Data}

Teknik analisa data merupakan suatu cara yang ditempuh guna memperoleh atau menganalisis data yang diperoleh. Analisa data bertujuan untuk kebenaran hipotesis yang dirumuskan.

\section{Uji Normalitas}

Uji normalitas dilakukan sebagai bahan pertimbangan yang digunakan untuk menguji normalitas data, maka diperlukan daftar distribusi frekuensi untuk menentukan ratarata, standar deviasi, dan modus.

$$
\mathrm{Km}=\frac{\bar{x}-M o}{s}
$$

(Sudjana, 2002:109)

\section{Uji Hipotesis}

Uji hipotesis dilakukan untuk mengetahui apakah ada pengaruh permainan sepak bola terhadap peningkatan kebugaran jasmani di SMA Srijaya Negara Palembang. Adapun hipotesis yang diuji kebenarannya, yaitu bila data yang diperoleh berdistribusi normal, maka digunakan rumus statistic uji t $(\mathrm{t}-\mathrm{Test})$. 


$$
t=\frac{\mathrm{Md}}{\sqrt{\frac{\sum \mathrm{X}^{2} \mathrm{~d}}{\mathrm{~N}(\mathrm{~N}-1)}}}
$$

(Sudjana, 2002:109)

\section{HASIL DAN PEMBAHASAN}

\section{Uji Normalitas Hasil Posttest}

Uji normalitas data digunakan untuk mengetahui apakah data yang akan diolah normal atau tidak. Sebab uji statistic ini baru bisa digunakan apabila data tersebut berdistribusi normal. Berdasarkan data dari distribusi frekuensi maka dapat menentukan rata-rata $(\bar{x})$, simpangan baku $\left(\mathrm{S}^{2}\right)$ dan modus (Mo).

TABEL 4. Distribusi Frekuensi Nilai

\begin{tabular}{|c|c|c|c|c|c|}
\hline Interval & $\boldsymbol{F i}$ & $\boldsymbol{X i}$ & $\boldsymbol{f i x i}$ & $\boldsymbol{x i}^{\mathbf{2}}$ & $\boldsymbol{f i x i}^{\mathbf{2}}$ \\
\hline $8-9$ & 3 & 8,5 & 25,5 & 72,25 & 216,75 \\
\hline $10-11$ & 11 & 10,5 & 115,5 & 110,25 & 1212,75 \\
\hline $12-13$ & 9 & 12,5 & 112,5 & 156,25 & 1406,25 \\
\hline $14-15$ & 1 & 14,5 & 14,5 & 210,25 & 210,25 \\
\hline $16-17$ & 1 & 16,5 & 16,5 & 272,25 & 272,25 \\
\hline Jumlah & 25 & 62,5 & 284,5 & 821,5 & 3318,25 \\
\hline
\end{tabular}

(1) Nilai rata-rata kelas eksperimen

$$
\begin{aligned}
\bar{x} & =\frac{\Sigma f_{i} x_{i}}{\Sigma f_{i}} \\
& =\frac{284,5}{25} \\
& =11,38
\end{aligned}
$$

(2) Modus ( Mo ):

Kelas modus dengan melihat bahwa :

$$
\begin{array}{rlr}
\mathrm{B} \quad=10 & \quad \mathrm{~b}_{1}=11-3=8 \\
\mathrm{~b}_{2} \quad=11-9=2 \quad \mathrm{p}=1 \\
\mathrm{Mo}= & \mathrm{b}+\mathrm{p}\left(\frac{b 1}{b 1+b 2}\right) \\
= & 10+1\left(\frac{8}{8+2}\right) \\
= & 10+1\left(\frac{8}{10}\right) \\
= & 10+0,8
\end{array}
$$

$$
=10,8
$$

Berdasarkan hasil rata-rata, modus, dan simpangan baku dapat dicari koefisien kemiringan dengan rumus karl pearson, yaitu :

$$
\begin{aligned}
\mathrm{SK} & =\frac{\bar{x}-M o}{S} \\
& =\frac{11,38-10,8}{1,83} \\
& =0,32
\end{aligned}
$$

Berdasarkan perhitungan di atas, nilai SK adalah 0,32 dan karena nilai SK sebesar 0,32 ini terletak antara (-1) dan (+1). maka data tersebut berdistribusi normal.

\section{Uji Hipotesis}

Setelah pengujian normalitas data sehingga data tersebut dinyatakan berdistribusi normal maka tahap selanjutnya yang dilakukan adalah pengujian hipotesis penelitian dengan menggunakan statistic parametris.

$$
\mathrm{Md}=\frac{\sum d}{\mathrm{~N}}=\frac{32}{25}=1,28
$$

Kemudian tes signifikansi dicari dengan rumus : $\quad t=\frac{\mathrm{Md}}{\sqrt{\frac{\sum \mathrm{X}^{2} \mathrm{~d}}{\mathrm{~N}(\mathrm{~N}-1)}}}=\frac{1,28}{\sqrt{\frac{5,04}{25 \times 24}}}$ $t=12,8$ (dikonsultasikan dengan table nilai $\mathrm{t}$ ) d.b. $=\mathrm{N}-1=25-1=24$

\section{Pembahasan}

Penelitian ini dilatar belakangi oleh rendahnya tingkat kebugaran jasmani siswa putra di SMA Srijaya Negara Palembang, sehingga apabila siswa sudah melakukan pembelajaran penjasorkes, siswa merasa lelah setelah melakukan aktivitas olahraga, hal ini terkesan bahwa kegiatan olahraga membuat 
badan mereka lelah. Adapun bentuk permainan yang diberikan untuk melihat pengaruh terhadap peningkatan kebugaran jasmani adalah bermain sepak bola selama $2 \mathrm{x}$ 20 menit. Penelitian ini dilakukan pada 25 orang siswa putra SMA Srijaya Negara Palembang. Penelitian ini adalah penelitian eksperimen dengan system Sampling Purposive, yaitu 25 orang siswa putra diberi perlakuan berupa latihan bermain sepak bola selama 2 x 20 menit yang bervariatif selama 4 minggu dengan frekuensi 4 kali seminggu.

Hasilnya tingkat kebugaran jasmani siswa putra SMA Srijaya Negara Palembang setelah uji Post-test lebih tinggi dengan nilai rata-rata 11,36 jika dibandingkan dengan hasil pre-test sebelumnya dengan nilai rata-rata 10,08. Hal ini disebabkan oleh proses latihan dengan bermain selama 2 x 20 menit yang bervariatif. Kemudian dilakukan tes signifikan dengan taraf kepercayaan $95 \%$ maka harga t_hitung $=12,8$, harga $\mathrm{t}$ kritik pada 【t.s.】 $\_0,05=1,71$ Maka $1,71<12,8$.

\section{SIMPULAN}

Dari hasil penelitian dan pembahasan dapat disimpulkan bahwa lama permainan sepak bola untuk siswa SMA selama 2 x 20 menit, dapat meningkatkan kebugaran jasmani siswa putra di SMA Srijaya Negara Palembang.

Pengujian hipotesis dengan dilakukan tes signifikan dengan taraf kepercayaan $95 \%$ maka harga $\mathrm{t}=12,8$, harga $\mathrm{t}$ kritik pada 『t.s. 』_0,05 =1,71 dan 【t.s.】_0,01=2,49. Maka $1,71<2,49<12,8$. Perbedaan antara hasil pre-test dengan post-test signifikan, karena eksperimen mempunyai pengaruh pada taraf signifikan 0,05 dan 0,01 . Berdasarkan hipotesis yang telah dikemukakan yaitu ada pengaruh permainan sepak bola terhadap peningkatan kebugaran jasmani siswa putra SMA Srijaya Negara Palembang (Ha) diterima.

\section{DAFTAR PUSTAKA}

Ajick. 2009. Pidato Guru Besar. Diakses melalui http:// pustaka.uns.ac.id/?menu $=$ news\&option=detail\&nid=124, diunduh tanggal 14 Maret 2016.

Arikunto, Suharsimi. 2013. Prosedur Penelitian Suatu Pendekatan Praktik. Jakarta : Rineka Cipta.

Luxbacher, Joseph A. 2011. Sepak Bola Edisi Kedua. Jakarta : PT Rajafrafindo Persada.

Nurhasan. 2001. Test dan Pengukuran Dalam Pendidikan Jasmani. Jakarta Pusat: Direktorat Jendral Olahraga.

Priatama, Novandi. 2009. Pengaruh Permainan Futsal Terhadap Peningkatan Kebugaran Jasmani Siswa Putra SMA Muhammadiyah 9 Palembang. Skripsi Palembang : Universitas PGRI

Sora N. 2015. Pengertian Populasi Dan Sampel Serta Teknik Sampling. Diakses melalui http : // www.pengertianku.net/2015/03/ pengertian - populasi-dan - sampel serta-teknik-sampling.html. diunduh tanggal 21 Januari 2016. 
Sudjana. 2002. Metoda Statistika. Bandung: Tarsito.

Sugiyono. 2014. Metode Penelitian Pendidikan Pendekatan Kuantitatif, Kualitatif dan R\&D. Bandung : Alfabeta.

Sukirno. 2011. Dasar-dasar Fisiologi Olahraga. Palembang : Universitas Sriwijaya. 